\title{
THE IMPACT OF MASS CUSTOMISATION ON THE QUALITY MANAGEMENT SYSTEM IN A SALES AND MARKETING ENVIRONMENT - A CASE STUDY
}

\author{
FJ Joubert ${ }^{1}$ and MC Bekker ${ }^{2}$ \\ ${ }^{2}$ Department of Engineering and Technology Management \\ University of Pretoria, South Africa \\ mcbekker@eng.up.ac.za
}

\begin{abstract}
The introduction of a vehicle platform destined for world-wide export brought mass customisation to the South African subsidiary of a German luxury car manufacturer. This, together with a $29 \%$ head count reduction, a model range increase, stringent profitability targets and increased customer satisfaction demands, made the previous, unintegrated quality systems used in the Sales and Marketing Division obsolete. A quality management system (QMS) based on ISO 9002 was implemented. To solve some of the problems in the mass customisation process, the principles of customer satisfaction and the measurement of internal processes were used to make recommendations for operational improvements.
\end{abstract}

\section{OPSOMMING}

Die produksie van voertuie wat in groot volumes wêreldwyd uitgevoer word, het bouvolgens-bestelling na die Suid-Afrikaanse filiaal van ' $n$ Duitse luukse voertuigvervaardiger gebring. Tesame met ' $n 29 \%$ personeelvermindering, ' $n$ verhoging in die getal beskikbare modelle, streng winsgewendheidsdoelwitte en verhoogde kliëntetevredenheidvereistes, het dit die vorige, ongeïntegreerde kwaliteitstelsels in die Verkope-en-Bemarkingsafdeling in onbruik laat verval. ' $\mathrm{n}$ Kwaliteitsbestuurstelsel gebaseer op ISO 9002 is geïmplementeer. Die beginsels van kliëntetevredenheid en die meting van falings in interne prosesse word gebruik om verbeteringsvoorstelle te doen om sodoende bedryfsbestuur te verbeter.

\footnotetext{
${ }^{1}$ The author was enrolled for the M Eng (Technology Management) at the Department of Engineering and Technology Management, University of Pretoria
} 


\section{INTRODUCTION}

The industrial revolution that started in the 19th century brought about mass production. Standardised products were manufactured and costs were kept down by economies of scale. The 20th century in turn brought about a customer revolution. Customers started demanding customised products and services at acceptable prices [1].

The definition and advantages of mass customisation. Gordon [2] defines mass customisation as the process of profitably providing and supporting individually tailored goods and services, according to each customer's preferences of form, time, place and price. There are several advantages to a mass customisation strategy. Lower costs are achieved through economies of scope - the application of a single process to produce a greater variety of products or services more cheaply and quickly [3]. Peppers and Rodgers [4] state that the mass customisation process allows customers to participate in the actual design of their own product. Consequently, the customer is much more likely to be satisfied with the overall performance of the product. It is also possible to add price premiums onto these products, since they meet specific customers' needs. A customised product, in the form the customer wants may have little or no competition, thereby ensuring pricing advantages [5]. Mass customisation can offer a progression of "new" products. Flexibility in design and manufacturing can enable a company to launch a continuous stream of product improvements that are new to customers [5]. Mass customisers can respond quicker to changes in markets, technology, standards and trends because of operational flexibility [5].

The requirements for a successful mass customisation strategy. There are several requirements for a successful mass customisation strategy. These include: (i) redesigning of business processes to break down the vertical compartments by examining the value chain of the company in a horizontal, logical customer-focused manner; (ii) compressing cycle times through all processes in the value chain, thus eliminating waste to increase flexibility and responsiveness; (iii) the ability to produce upon receipt of order instead of a forecast (this brings advantages such as lowered inventory costs, decrease in write-offs and provides the information necessary for individual customisation [3]); (iv) development of the ability to rapidly change products or services, structural arrangements, as well as organisational orientation towards product requirements. Radder and Louw [1] mention that the organisation requires the following to achieve the benefits of mass customisation: (i) a flexible and less hierarchical structure, functional teams and positive feedback loops; (ii) re-engineering of processes to provide the required flexibility and quick response, as well as (iii) the commitment and involvement of employees, suppliers, distributors and customers.

Mass customisation at the South African original equipment manufacturer (OEM). The introduction of a new model in 1998 brought mass customisation to the South African OEM. Vehicles were now produced at German levels of customer satisfaction, quality, cost and productivity. The main advantage for the Sales and Marketing Division was that it could now fulfil customer demand by offering any client a new, locally produced vehicle - each individual vehicle built to order. The number of options available for customers to choose from increased from 50 in 1997 to 157 in 2000 . This availability of the customer selectable options forms the basis of mass customisation at the South African OEM. 
Problems relating to mass customisation at the South African OEM. Ålström and Westbrook [6] identified several problems that can be found during mass customisation processes. These include (i) poorer on-time deliveries; (ii) decreases in supplier delivery performance; (iii) increased order response time; (iv) delays in model introduction; (v) reduction in product quality as well as (vi) problems with information technology. Their findings were confirmed by certain events at the OEM.

The increase in production volume and complexity of the new model resulted in severe strain on the systems used by the Sales and Marketing Division. Mass customisation requires, by nature of the concept, that vehicles should be built to order and not to forecast. This also means that mass customisation requires redesigning of processes. To address some of these complexities, the Ordering and Distribution Department introduced a QMS based on ISO 9002 in 1997. This QMS was closely related to the production and volume-planning processes at the OEM's plant, but did not cover interaction between other departments within the Sales and Marketing Division. Mass customisation caused other problems as well such as more complex pricing and difficulties within change management. The ordering system had to be substantially adjusted to accommodate the availability of options. The complexity of all internal and external communication increased because of the increase in the number of bulletins to the dealer network as well as the increase in the number of price lists and option descriptions. As part of rationalization the number of employees was also decreased form 280 to 200 in the department.

Conclusion. With mass customisation as the main driving force, a $29 \%$ headcount reduction, a model range increase, more taxing profitability targets and increased customer satisfaction demands, the previous, un-integrated quality management systems used in the Sales and Marketing Division became insufficient. A QMS was required to supply structure to the processes supporting a product that was becoming more and more complex. The QMS also needed to define the interdepartmental relationships and responsibilities within the Sales and Marketing Division. A proper system dealing with corrective action and process measurement was also required. A summary of the influence of mass customisation on the OEM's Sales and Marketing Division is given in Table 1.

\begin{tabular}{|l|c|c|}
\cline { 2 - 3 } \multicolumn{1}{c|}{} & Before mass customisation & After mass customisation \\
\hline Number of options & 50 & 157 \\
\hline Number of models & 10 & 20 \\
\hline Headcount & 280 & 200 \\
\hline Annual training expenditure & R4.2 million & R8.9 million \\
\hline Pricing & $\begin{array}{c}\text { Simple, few models and op- } \\
\text { tions }\end{array}$ & $\begin{array}{c}\text { Complex, more models and } \\
\text { options }\end{array}$ \\
\hline Ordering system (internal & Based on forecast & Based on order \\
\hline $\begin{array}{l}\text { Communication complex - less variety } \\
\text { and with dealer network) }\end{array}$ & $\begin{array}{c}\text { More complex because of } \\
\text { variety and complexity of } \\
\text { product }\end{array}$ \\
\hline
\end{tabular}

Table 1: The influence of mass customisation on the Sales and Marketing Division (1997 - 2000) 


\section{DECISION TO INSTALL A QMS BASED ON ISO 9000}

Due to the measurement requirements associated with a quality management system, the implementation of a QMS in a non-production environment proved to be challenging. The ISO 9000 quality objectives of (i) achieving consistent customer satisfaction; (ii) giving management the confidence that quality is being produced and (iii) giving the customer confidence that quality is being delivered, supported the objectives of the Sales and Marketing Division [7]. It was therefore decided to base the QMS on the principles of ISO 9000. A QMS was installed throughout the entire Sales and Marketing Division and was certified by TÜV South Africa in June 1999.

Problems after the introduction of a QMS. Since the introduction and certification of the QMS, certain problems and incidents occurred that highlighted discrepancies in the current processes. These included problems with on-time deliveries, information technology, supplier delivery performance and delays in model introduction. The following paragraphs describe some of the incidents that occurred through the system.

Incident 1: The sport utility vehicle (SUV) and all-terrain tyres. The SUV was introduced to the South African market in March 2001. The vehicle was released in Germany with 17" rims and normal 17" tyres. The option of being able to choose between normal and all-terrain tyres was new to the OEM. The South African vehicle profile had 18" rims and all-terrain tyres as a 100\% option - meaning all vehicles had to have 18 " rims fitted with allterrain tyres. An additional option was subsequently introduced and 19" rims, again with allterrain tyres, were also released and a large number of vehicles with this option were ordered in Europe. When placing the orders for the launch vehicles in South Africa, the distribution specialist, responsible for entering the vehicle profile on the ordering system, interpreted allterrain tyres as a type of rim and removed the 18" and 19" all-terrain tyres from the profile. The German central ordering system defaulted the order to 17 " rims with normal tyres. This was only noticed when the first vehicles arrived in South Africa. A total of 38 vehicles were affected and 190 rims and tyres had to be air-freighted to South Africa at a total cost of nearly R600 000.

Incident 2: The SUV and spare wheels. The availability of the full size spare wheel was not included in any of the German status reports until 22 February 2001. At that time, all the vehicles for the product launch had already been built and equipped with a space-saver spare wheel. Because of the road conditions in South Africa, this was not considered to be a viable alternative. A total of 312 vehicles had to be refitted with the correct spare rims and tyres.

Incident 3: The touring model without roof rails. The touring model was introduced to the South African market in September 2000. It was initially released with the roof rails as an option. After one month of production, this was changed to a $100 \%$ option. A total of 42 units had to be reworked. The parts used for this rework were $20 \%$ more expensive than factory-fitted parts.

Structuring the QMS and compiling the procedures. As part of the exercise of compiling an integrated process supporting the processes involved in mass customisation, a number of problems were identified within the QMS. The structure within the QMS is broken down to 
department level. As Pine [3] states, one of the requirements of mass customisation is a redesigning of business processes that breaks down the vertical compartments that exist between departments. If the procedures were broken down to process level, problems such as procedures not being complete and not conforming to the guidelines for documents as described in the QMS might have been avoided. Examples of these shortcomings were missing reference to quality records and descriptions of terminology used. Omissions like these contributed to the lack of transparency in some procedures [8]. Processes were often viewed in isolation. The entire mass customisation process and the mass customisation procedures were not described in detail. There were no procedures to be found that described how to deal with and document the actions that took place when non-conforming vehicles were received.

The problems that occur within the mass customisation process seem few in number but high in cost and occurring in both product planning and ordering. Although the procedures in the QMS have brought a certain degree of transparency to these processes, the latter still need to be improved to achieve the required quality results. No integrated mass customisation procedure existed. To improve the procedure, the entire mass customisation process had to be evaluated.

\section{IMPROVING THE QMS: PROCESS MEASUREMENT AND CUSTOMER SATISFACTION}

Process measurement. Measurement is needed to improve the quality environment by assessing the extent to which customer requirements have been met [9]. It also provides standards for creating comparisons; it creates visibility within processes so that the users can measure their own performance and it gives an indication of the costs of poor quality. The guidelines for quality management and quality system elements published by the South African Bureau of Standards [7] also require that processes directly affecting quality should be carried out under controlled conditions. These controlled conditions include monitoring and controlling suitable process parameters and product characteristics. In the next paragraphs, the decision to concentrate on the measurement of customer satisfaction and the failure of internal processes are explained.

Customer satisfaction reflects quality. As Schönberger and Knod [10] point out, the concepts of quality continue to evolve but the pioneering works of W.E. Deming, A.V. Feigenbaum and P.B. Crosby still have a profound influence on the management of quality. Because the improvement of customer satisfaction was seen as one of the major reasons for implementing a quality management system, it is worthwhile noting what the above quality experts had to say about the importance of customer satisfaction.

Feigenbaum [10] concluded that control over a process must start with identification of customer quality requirements and end only when the product has been placed in the hands of a customer who remains satisfied. Crosby [10] concurred in his definition that quality is the conformance to requirements all the time. In the first of his 14 Points, Deming [10] states that to become competitive and to stay in business, constancy of purpose to improve products and services must be created. The guidelines for quality management and quality system elements published by the South African Bureau of Standards [7] support this by stating that in order to be successful, an organisation should offer products that meet the demands of customers. The same publication also states that a quality system should be developed and implemented to 
achieve the objectives as described in the organisation's quality policy. The quality policy of the Sales and Marketing Division supports this by stating that "in keeping with the OEM's Quality Management System Principles of quality being the first priority, customer orientation and continuous improvement, the OEM's Sales and Marketing Division commits itself to efficiently delivering best in class services and products to dealers, customers and internal staff".

\begin{tabular}{|c|c|c|c|c|}
\hline Name & $\begin{array}{l}\text { What is being } \\
\text { measured }\end{array}$ & Method & Frequency & $\begin{array}{c}\text { Time be- } \\
\text { tween the } \\
\text { event and } \\
\text { report }\end{array}$ \\
\hline $\begin{array}{l}\text { CCSI (Com- } \\
\text { petitive cus- } \\
\text { tomer } \\
\text { satisfaction } \\
\text { index) }\end{array}$ & $\begin{array}{l}\text { Every six months. } \\
\text { Brand performance } \\
\text { in sales and service. } \\
\text { Industry wide sur- } \\
\text { vey. }\end{array}$ & $\begin{array}{l}\text { Telephonic } \\
\text { interview, } 34 \\
\text { questions. }\end{array}$ & $\begin{array}{l}\text { Sales: After first year of } \\
\text { ownership. } \\
\text { Service: Various inter- } \\
\text { vals with the provision } \\
\text { that the customer had a } \\
\text { vehicle serviced. }\end{array}$ & $\begin{array}{l}\text { Up to one } \\
\text { year. }\end{array}$ \\
\hline $\begin{array}{l}\text { CSI (Cus- } \\
\text { tomer satis- } \\
\text { faction } \\
\text { index) }\end{array}$ & $\begin{array}{l}\text { Every six months. } \\
\text { Dealer performance } \\
\text { in sales and service. } \\
\text { OEM proprietary } \\
\text { survey. }\end{array}$ & $\begin{array}{l}\text { Mailed ques- } \\
\text { tionnaire, } 104 \\
\text { questions. }\end{array}$ & $\begin{array}{l}\text { Sales: Three months } \\
\text { after purchase. } \\
\text { Service: After one and } \\
\text { two years of ownership } \\
\text { with the provision that } \\
\text { the customer had a ve- } \\
\text { hicle serviced. }\end{array}$ & $\begin{array}{l}\text { Up to six } \\
\text { months. }\end{array}$ \\
\hline $\begin{array}{l}\text { S-CSI } \\
\text { (Short cus- } \\
\text { tomer satis- } \\
\text { faction } \\
\text { index.) }\end{array}$ & $\begin{array}{l}\text { Monthly dealer per- } \\
\text { formance in sales } \\
\text { and service. OEM } \\
\text { proprietary survey. }\end{array}$ & $\begin{array}{l}\text { Telephonic } \\
\text { interview, } 14 \\
\text { questions. }\end{array}$ & $\begin{array}{l}\text { Sales: Three months } \\
\text { after purchase. } \\
\text { Service: After the cus- } \\
\text { tomer had a vehicle ser- } \\
\text { viced. }\end{array}$ & $\begin{array}{l}\text { Up to one } \\
\text { month. }\end{array}$ \\
\hline $\begin{array}{l}\text { Dealer } \\
\text { Survey }\end{array}$ & $\begin{array}{l}\text { How the dealers ex- } \\
\text { perience the Sales } \\
\text { and Marketing Divi- } \\
\text { sion. OEM proprie- } \\
\text { tary survey. }\end{array}$ & $\begin{array}{l}\text { Written ques- } \\
\text { tionnaire. }\end{array}$ & Annually. & $\begin{array}{l}\text { Up to one } \\
\text { year. }\end{array}$ \\
\hline
\end{tabular}

Table 2: Summary of customer satisfaction surveys

Quality as a measure of internal processes. Juran [9] states that the unit of measurement of quality is the cost of quality, including the cost of inspection and the cost of nonconformance. Feigenbaum [9] supports this by distinguishing between appraisal, prevention and failure costs. As seen in previous paragraphs, the cost of non-conformance in the mass customisation process can be significant. Feigenbaum's quality improvement programme's goal is the reduction of the cost of quality. To achieve this, the tracking of cost of quality has to be included in a QMS [9]. It must also be ensured that the targets, as prescribed in the annual target commitment process, are being reflected in the processes that support the mass customisation process. 


\section{THE MEASUREMENT OF CUSTOMER SATISFACTION AT THE OEM}

The OEM conducts four customer satisfaction surveys to enable customers to give feedback of their experience with the OEM, thus enabling the OEM to implement corrective action where necessary. A summary of the customer satisfaction surveys appears in Table 2.

The influence of mass customisation on the customer satisfaction surveys. When examining the questions in the CCSI questionnaire, it became clear that some questions were influenced by mass customisation. These questions include: (i) "Did the salesperson provide information on various optional extras for the car?"; (ii) "Did the salesperson have enough product knowledge?"; (iii) "Was the salesperson able to clearly explain technical features?" and (iv)"Did the salesperson provide information on the safety and security features of the vehicle?". Mass customisation brings variety. This can cause problems when inadequately trained sales persons are asked questions that relate to a variety of options.

Corrective action implemented to solve problems relating to customer satisfaction. Two major issues were identified. The first was that not all processes influencing customer satisfaction were measured and managed. The second relates to shortcomings in the customer satisfaction survey process. To ensure continuous improvement and increased customer satisfaction, these issues needed to be addressed in the QMS. These issues mainly relate to matters that are important to customers but which are not being dealt with in the QMS. From Table 2, it is evident that should customers not be satisfied with a certain issue, it can take up to one year for the feedback to reach the OEM. From the QMS, it was also evident that no one was responsible for quality management relating to customer satisfaction.

Because mass customisation can greatly contribute to customer satisfaction, it is essential to adequately manage customer satisfaction survey results. Traditionally, customer satisfaction was seen as the responsibility of the Service Department. After investigations, it was evident that other departments could also provide input and that there was no centrally coordinated management of customer satisfaction survey results.

In June 2001, a new department called Customer Relationship Management (CRM) was created. The tasks of this department include the co-ordination of all contact points between the OEM, the OEM's South African dealer network and the customers. Because customer satisfaction is such an important issue, the new department was tasked to solve the problems that had a bearing on the quality management of the processes relating to the customer satisfaction surveys. The new process is outlined and described in Figure 1.

To support the process described above, a new process giving the dealer network and the CRM department feedback on the effectiveness of corrective action had to be implemented. The process is outlined in Figure 2.

The priority issues identified in Step 2 are based on the two weakest areas of each individual dealer. This means that if on-time delivery was identified as a problem for a specific dealership, a question similar to "Was your vehicle delivered on time" will be put to the customers during the telephonic interview. 
Results are based on the three-month rolling average scores for the identified problem areas. The questions are changed as more important issues are identified. The advantages of the process described above include month-to-month feedback to the OEM and the dealer network, as well as faster implementation of corrective action. The process is cyclic and results are reported every month.

\begin{tabular}{|c|c|c|}
\hline Step 1 & $\begin{array}{l}\text { Customer } \\
\text { Satisfaction } \\
\text { results received }\end{array}$ & $\begin{array}{l}\text { The Marketing Research Department receives the } \\
\text { results of the various customer satisfaction surveys. }\end{array}$ \\
\hline Step 2 & $\begin{array}{c}\downarrow \\
\text { Results } \\
\text { Analyzed }\end{array}$ & $\begin{array}{l}\text { Weaknesses at specific dealers, as well as weak ar- } \\
\text { eas within the entire dealer network, are identified. }\end{array}$ \\
\hline Step 3 & $\begin{array}{c}\boldsymbol{\nabla} \\
\text { Status on } \\
\text { Satisfaction } \\
\text { updated on } \\
\text { graphs }\end{array}$ & $\begin{array}{l}\text { After a discussion between the CRM and Marketing } \\
\text { Research Departments, the priority issues are identi- } \\
\text { fied and updated on publicly displayed graphs. The } \\
\text { responsible departments are also identified. Clear } \\
\text { benchmarks are defined. }\end{array}$ \\
\hline Step 4 & $\begin{array}{c}\text { Corrective } \\
\text { Action Requests } \\
\text { issued }\end{array}$ & $\begin{array}{l}\text { The CRM Department issues corrective action re- } \\
\text { quests and manages the reporting on the status of } \\
\text { the implemented corrective actions. The results are } \\
\text { displayed in public. The process is cyclic and re- } \\
\text { sults are reported every month. }\end{array}$ \\
\hline
\end{tabular}

Figure 1: Management of the results from customer satisfaction surveys

\section{THE MEASUREMENT OF NON-CONFORMING PRODUCT IN THE MASS CUSTOMISATION PROCESS}

Mass customisation procedure. Initially there was no procedure for the management of non-conforming products. To solve these problems, the vehicle process chain (VPC) (see figure 3) was used as a basis to describe the process of mass customisation. The VPC encompasses all processes involved in the vehicle lifecycle and is the same for all the German company's worldwide subsidiaries. Procedures available in the QMS were used as the basis for describing the relationship between the VPC and the Sales and Marketing Division. Where information was not available from the procedures, personnel supporting the procedures were interviewed. An integrated mass customisation procedure was formulated and the QMS was structured around this process. The new procedure makes provision for measurements and clearly defines cross-departmental responsibilities. 


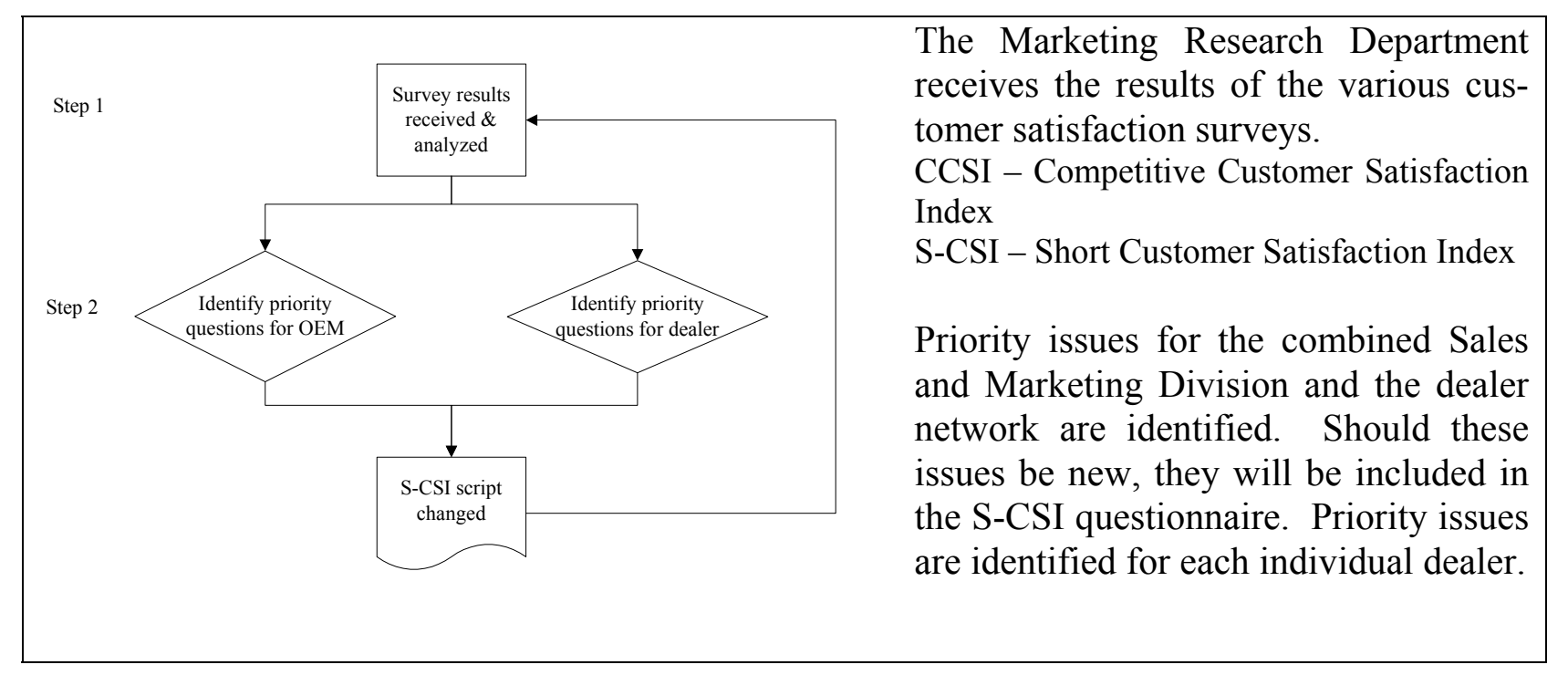

Figure 2: New questions for S-SI

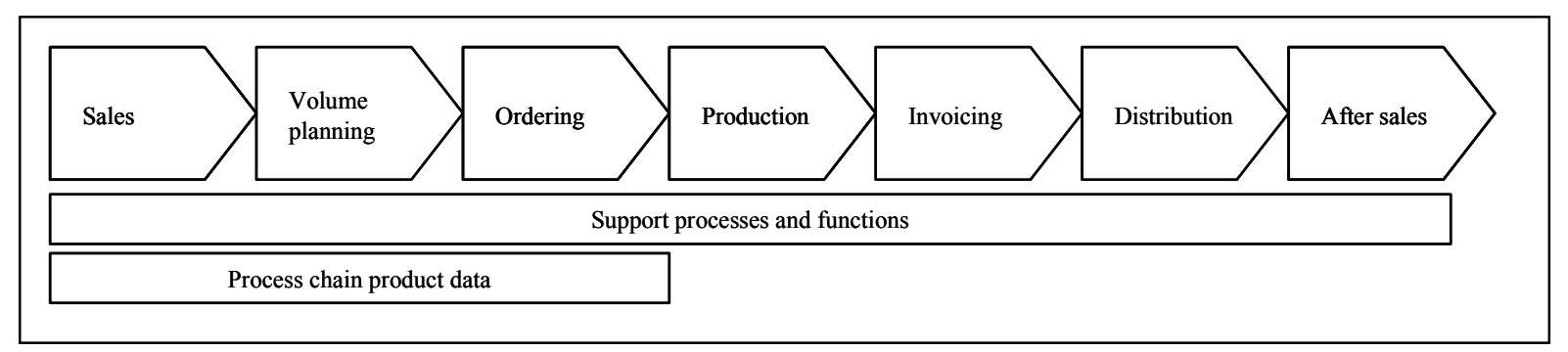

Figure 3: Vehicle process chain (VPC) [11]

After the mass customisation procedure was completed, interviews were conducted with employees responsible for certain tasks in the process. A summary of the questions and answers appears in Table 3.

Corrective action implemented in the management of non-conforming product. Because the Ordering and Distribution Department had a significant involvement in the process and a service agreement with the vehicle distribution centre, it was recommended that this department be the process owner of the process "Managing Non-Conforming Product". A procedure was compiled that included the following: (i) identifying the Ordering and Distribution Department as the process owner; (ii) a detailed process description with a checklist to support the problem-solving process; (iii) the provision for a register of incidents of nonconforming product and the cost involved; (iv) the use of a standard problem-solving sheet, as well as (v) identification of the process to be followed when reworking products. The advantages of using the procedure include (i) central control of non-conforming product; (ii) proper documentation of corrective actions and (iii) using a checklist to ensure that all the necessary steps are taken. The procedure was implemented in August 2001. 


\begin{tabular}{|c|c|c|c|}
\hline & \multicolumn{3}{|c|}{ DEPARTMENT } \\
\hline QUESTION & $\begin{array}{l}\text { VOLUME } \\
\text { PLANNING }\end{array}$ & $\begin{array}{l}\text { PRODUCT } \\
\text { PLANNING }\end{array}$ & $\begin{array}{l}\text { ORDERING AND } \\
\text { DISTRIBUTION }\end{array}$ \\
\hline $\begin{array}{l}\text { Departmental re- } \\
\text { sponsibilities. }\end{array}$ & $\begin{array}{l}\text { Planning and reporting } \\
\text { of production, whole- } \\
\text { sale and retail budgets } \\
\text { and forecasts. }\end{array}$ & $\begin{array}{l}\text { Supports process } \\
\text { chain product data. } \\
\text { Determines vehicle } \\
\text { profiles and pricing. }\end{array}$ & $\begin{array}{l}\text { Supports ordering and } \\
\text { distribution processes. }\end{array}$ \\
\hline \multirow[t]{2}{*}{$\begin{array}{l}\text { What in the proc- } \\
\text { ess costs the } \\
\text { OEM money? }\end{array}$} & $\begin{array}{l}\text { Wrong mix of product } \\
\text { being sold (higher con- } \\
\text { tribution on expensive } \\
\text { models). }\end{array}$ & $\begin{array}{l}\text { Wrong profiles caus- } \\
\text { ing rework of vehicles } \\
\text { in the vehicle distribu- } \\
\text { tion centre. }\end{array}$ & $\begin{array}{l}\text { Wrong profiles caus- } \\
\text { ing rework of vehicles } \\
\text { in the vehicle distribu- } \\
\text { tion centre. }\end{array}$ \\
\hline & $\begin{array}{l}\text { Too much or too little } \\
\text { stock. }\end{array}$ & $\begin{array}{l}\text { Having the wrong } \\
\text { product available. }\end{array}$ & $\begin{array}{l}\text { Vehicles not delivered } \\
\text { on time. }\end{array}$ \\
\hline \multirow{2}{*}{$\begin{array}{l}\text { When something } \\
\text { has gone wrong in } \\
\text { the process, how } \\
\text { do you know } \\
\text { about it? }\end{array}$} & \multirow{2}{*}{$\begin{array}{l}\text { Actual wholesale, retail } \\
\text { and stock volumes de- } \\
\text { viating from budget and } \\
\text { forecast. }\end{array}$} & $\begin{array}{l}\text { Rework of vehicles in } \\
\text { the vehicle distribu- } \\
\text { tion centre. }\end{array}$ & $\begin{array}{l}\text { Dealers complaining } \\
\text { about delayed vehi- } \\
\text { cles. }\end{array}$ \\
\hline & & $\begin{array}{l}\text { Models and options } \\
\text { not selling. }\end{array}$ & $\begin{array}{l}\text { Orders being rejected } \\
\text { by Germany. }\end{array}$ \\
\hline \multirow{2}{*}{$\begin{array}{l}\text { When something } \\
\text { goes wrong, what } \\
\text { corrective action } \\
\text { is implemented? }\end{array}$} & \multirow[t]{2}{*}{$\begin{array}{l}\text { Production request } \\
\text { changed, forecast } \\
\text { amended. }\end{array}$} & $\begin{array}{l}\text { Vehicles are reworked } \\
\text { in the vehicle distribu- } \\
\text { tion centre. }\end{array}$ & \multirow{2}{*}{$\begin{array}{l}\text { Procedure in place to } \\
\text { handle feedback to } \\
\text { dealers regarding de- } \\
\text { layed units. }\end{array}$} \\
\hline & & $\begin{array}{l}\text { Vehicle profile } \\
\text { changed. }\end{array}$ & \\
\hline $\begin{array}{l}\text { How do you } \\
\text { know that there is } \\
\text { quality in the } \\
\text { work you do? }\end{array}$ & $\begin{array}{l}\text { Meeting budget and } \\
\text { forecast on wholesale, } \\
\text { retail and stock. }\end{array}$ & $\begin{array}{l}\text { Meeting the retail } \\
\text { budget and forecast. }\end{array}$ & $\begin{array}{l}\text { Customer satisfaction } \\
\text { increases. }\end{array}$ \\
\hline \multirow{2}{*}{$\begin{array}{l}\text { Do you measure } \\
\text { the process? Are } \\
\text { there any reports? } \\
\text { Are they part of } \\
\text { the QMS? }\end{array}$} & \multirow[t]{2}{*}{$\begin{array}{l}\text { Yes, reports are issued } \\
\text { regularly. But it is not } \\
\text { mentioned in the QMS. }\end{array}$} & \multirow[t]{2}{*}{ No. } & $\begin{array}{l}\text { On-time delivery } \\
\text { measured but not re- } \\
\text { ported. }\end{array}$ \\
\hline & & & $\begin{array}{l}\text { Condition of cars on } \\
\text { delivery measured but } \\
\text { not reported. }\end{array}$ \\
\hline $\begin{array}{l}\text { Influence of mass } \\
\text { customisation }\end{array}$ & $\begin{array}{l}\text { Not significant. Pro- } \\
\text { duction volume of a } \\
\text { certain model is } \\
\text { planned for. Options } \\
\text { are not considered in } \\
\text { the process. }\end{array}$ & $\begin{array}{l}\text { Significant. Depart- } \\
\text { ment decides on } \\
\text { which options and } \\
\text { models become avail- } \\
\text { able, when and at } \\
\text { what price. }\end{array}$ & $\begin{array}{l}\text { Significant. Systems } \\
\text { must be able to order } \\
\text { the released options. } \\
\text { Options that are not } \\
\text { released should not be } \\
\text { allowed to be ordered. }\end{array}$ \\
\hline Comments & $\begin{array}{l}\text { Well-controlled proc- } \\
\text { ess. }\end{array}$ & \multicolumn{2}{|c|}{$\begin{array}{l}\text { Condition of cars on delivery measured but not } \\
\text { reported. }\end{array}$} \\
\hline
\end{tabular}

Table 3: Internal process measurement 


\section{SUMMARY}

The corrective action relating to the management of customer satisfaction survey results, as well as the management of non-conforming product in the mass customisation process, has already been implemented and is now part of the QMS. The effectiveness of these procedures will be evaluated against future customer satisfaction survey results, as well as the frequency and cost of non-conforming product. It is important to note that the responsibilities of this process have been clearly identified. Table 4 contains a summary of all the actions taken.

\begin{tabular}{|c|l|l|}
\cline { 2 - 3 } \multicolumn{1}{|c|}{ BEFORE INVESTIGATION } & \multicolumn{1}{|c|}{ AFTER INVESTIGATION } \\
\hline 1. & $\begin{array}{l}\text { No integrated procedure for the mass } \\
\text { customisation process existed. Proce- } \\
\text { dure was incomplete with no defined } \\
\text { measurements and cross-departmental } \\
\text { responsibilities. }\end{array}$ & $\begin{array}{l}\text { Integrated process compiled that includes } \\
\text { measurements and cross-departmental } \\
\text { responsibilities. QMS structured around mass } \\
\text { customisation process. }\end{array}$ \\
\hline 2. & $\begin{array}{l}\text { No procedure describing the control of } \\
\text { non-conforming product existed. }\end{array}$ & $\begin{array}{l}\text { Procedure implemented and controlled by Order- } \\
\text { ing and Distribution Department. Procedure } \\
\text { makes provision for the documentation of prob- } \\
\text { lem-solving activities as well as cost estimates. }\end{array}$ \\
\hline 3. & $\begin{array}{l}\text { No procedure controlling the man- } \\
\text { agement of customer satisfaction re- } \\
\text { sults. }\end{array}$ & $\begin{array}{l}\text { Procedure implemented and controlled by CRM } \\
\text { department. }\end{array}$ \\
\hline
\end{tabular}

Table 4: Summary of corrective action

\section{REFERENCES}

[1] Radder L and Louw L, 2000. "The readiness of selected South African organisations to mass customize", The TQM Magazine, MCB University Press.

[2] Gordon, I., Relationship Marketing, John Wiley \& Sons, 1998

[3] Pine BJ, 1993. "Mass customisation", Harvard Business School Press.

[4] Peppers D and Rodgers M, 1997. "Enterprise One to One", Doubleday Broadway Books.

[5] Anderson DM, 1997. "Revenue Gains Realized through Mass Customisation", McGraw Hill Professional Book Group.

[6] Ålström P and Westbrook R, 1999. "Implications of mass customisation for operations management: An exploratory survey", International Journal of Operations and Production Management, MCB University Press.

[7] "ISO 9001 Guidelines", 1994. South African Bureau of Standards, Pretoria.

[8] Michael G, 2001. Discussion, Midrand.

[9] Oakland JS, 1999. "Total Quality Management", Butterworth Heinemann, Bradford.

[10] Schonberger RJ and Knod EM, 1994. "Operations Mangement: Continuous improvement", Iwin, Boston, Massachusetts.

[11] “Quality Management Manual”, 2001. Automotive, 2001. 
